\title{
PENGARUH KEPUASAN KERJA DAN KOMITMEN LEMBAGA TERHADAP KINERJA DOSEN IAIN LANGSA
}

\author{
Yusaini \\ Dosen IAIN Langsa \\ Yusaini@febi.iainlanngsa.ac.id
}

j-EBIS

Jurnal Ekonomi dan Bisnis

Islam

Volume : 2

Nomor : 1

Halaman 1 - 14

Langsa, April 2017

ISSN : 2502-1397

E-ISSN : 2540-8100

\section{Abstrak}

Penelitian ini bertujuan untuk mengetahui faktor-faktor yang mempengaruhi kinerja dosen IAIN Langsa. Penelitian ini dilakukan di IAIN Langsa dengan melibatkan 84 dosen yang sedang aktif mengajar pada tahun akademik 2015/2016 dan semua dosen ditetapkan sebagai sampel penelitian. Variable dalam penelitian ini adalah kepuasan kerja, komitmen organisasi, dan kinerja dosen. Instrumen penelitian terlebih dahulu diuji coba, yaitu untuk menguji validitas dengan korelasi Product Moment dan untuk menguji reliabilitasnya dengan Formula Alpha dari Cronbach. Teknik analisis data dilakukan dalam dua tahap yakni secara deskriptif dan inferensial.

Uji persyaratan analisis mencakup uji normalitas dan uji linearitas regresi. Uji normalitas data setiap variable menggunakan One Sample Kolmogorov Smirnof Test. Uji kelinearan regresi antar variable dilakukan dengan menggunakan statistic $\mathrm{F}$ test. Sedangkan untuk menguji hipotesis digunakan analisis jalur (path Analysis). Hasil Penelitian diperoleh bahwa: (1) terdapat pengaruh secara signifikan kepuasan kerja terhadap kinerja dosen IAIN Zawiyah Cot Kala Langsa, dan (2) terdapat Pengaruh signifikan komitmen organisasi terhadap kinerja dosen IAIN Langsa. Berdasarkan hasil penelitian, kinerja dosen IAIN Langsa dipengaruhi oleh faktor kepuasan kerja, dan komitmen organisasi. Untuk itu, pimpinan IAIN Langsa perlu mengevaluasi bagaimana komitmen yang dibangun pada lembaga dan bagaimana pula upaya yang harus dilakukan agar kepuasan kerja dosen dapat dirasakan.

Keywords: Kepuasan Kerja, Komitmen Lembaga, dan Kinerja Dosen.

\section{PENDAHULUAN}

Organisasi atau lembaga menjadi sesuatu yang penting untuk diteli. Karena, organisasi perlu diupayakan untuk lebih maju, dan perlu adanya rasa bersaing dengan organisasi atau lembaga lain. Organisasi tumbuh maju karena orang-orang yang bekerja di dalamnya mampu bekerja sama dan bekerja keras. Mereka menghabiskan waktunya untuk bekerja demi kemajuan organisasinya. Berkenaan dengan hal ini Etzioni (1994) menuliskan bahwa: "Kita dilahirkan dalam organisasi, dididik oleh organisasi, dan hampir semua diantara kita menghabiskan hidup kita bekerja untuk organisas" ( Torang, 2013 :25). Dengan demikian, kita dapat mengartikan bahwa: Organisasi adalah suatu entitas sosial yang dikoordinasikan secara sadar oleh sekelompok orang yang 
menjalankan berbagai aturan dan bekerja secara terus menerus untuk meraih tujuan yang telah direncanakan ( Torang, 2013 :25).

Organisasi harus tumbuh dengan baik dan sehat. Karena organisasi yang sehat biasanya sangat bergantung pada pemimpin yang memegang kendali berputarnya roda organisasi. Karena orang-orang yang bekerja dalam sebuah organisasi membutuhkan arahan, petunjuk dan aturan untuk bekerja. Setiap organisasi memiliki cara, kebiasaan, dan aturan dalam mencapai tujuan dan misi organisasi. Orang-orang akan berinteraksi dalam melakukan pekerjaan sesuai dengan perilaku masing-masing. Perilaku individu yang ada dalam organisasi berupaya melaksanakan program kerja yang telah disepakati ataupun diembannya dan akan menunjukkan suatu kinerja yang menggambarkan seberapa efektif mereka bekerja dalam mencapai tujuan bersama dalam organisasi(Armanu Thoyib, 2005 : 3-4). Oleh karena itu, keberhasilan sebuah organisasi akan dipengaruhi oleh seberapa efektifnya orang-orang yang bekerja dalam organisasi itu. Artinya, roda organisasi dapat berputar dengan baik dalam menumpuh tujuan sangat bergantung pada kinerja yang mampu ditunjukkan oleh anggota organisasinya.

Kita misalkan kinerja dosen IAIN Langsa bergantung pada kualitas sumberdaya manusia yang ada di dalamnya. Pimpinan IAIN Langsa bersama-sama dengan Kementerian Agama Republik Indonesia harus memberdayakan dosen-dosen di lingkungannya dengan berbagai fasilitas yang berkualitas. Misalnya, dengan menyediakan program beasiswa pendidikan lanjutan bagi dosen, menyediakan fasilitas kerja yang memadai, memberikan pelatihan-pelatihan, menyediakan sarana dan prasarana di kampus dengan tekhnologi yang tinggi, menyediakan dana hibbah penelitian yang bervariasi, dan berbagai program peningkatan SDM lainnya. Dengan cara-cara seperti ini, SDM dosen di lingkungan IAIN langsa akan memberikan kemampuan kerja yang signifikan dalam menghasilkan kinerja yang bermutu (Heri Sudarsono, 2008:12-23).

IAIN Langsa harus berpuya menyediakan berbagai fasilitas bagi dosen agar dapat bekerja dengan baik. Jika fasilitas kerja telah dapat dipenuhi, maka perguruan tinggi akan memperoleh kinerja dosen yang diinginkan. Kejujuran dalam bekerja, ketaatan dan kedisiplinan dosen dalam melaksanakan tugas akan dapat ditunjukkan pada setiap aktivitas dalam pencapaian tujuan perguruan tinggi. Hal itu dapat dinilai dari kinerja yang ditampilkan pada setiap aktivitas dan kegiatan yang dilakukan dalam perguruan tinggi.

Pada perguruan tinggi, bentuk penilaian prestasi kerja atau kinerja terangkum dalam Daftar Penilaian Pelaksanaan Pekerjaan, dimana daftar tersebut memuat 10 indikator yang ada. Indikator-indikator tersebut meliputi: kesetiaan, prestasi kerja, tanggung 
jawab, ketaatan, kejujuran, kerjasama, prakarsa, dan kepemimpinan (Heri Sudarsono, 2008:12-23). Dosen-dosen di lingkungan IAIN Langsa di diharapkan memiliki ke-sepuluh indikator ini. Sebab, apabila indikator-indikator ini dimiliki setiap dosen IAIN Langsa, maka dapat saja diestimasikan bahwa sebesar apapun tujuan dari lembaga pendidikan akan dapat dicapai dengan maksimal.

Kinerja dosen merupakan perihal utama yang harus diberdayakan oleh IAIN Langsa. Karena kinerja adalah ujung tombak yang menjadi harapan setiap perguruan tinggi dalam upaya membangun dan menuju perguruan tinggi yang bermutu. Kinerja dosen di perguruan tinggi dapat dilihat dengan output dosen dalam melaksanakan aktivitasnya.

Berkaitan dengan kinerja dosen, Dirjen Dikti (2000) dalam mendeskripsikan beban kerja normal seorang dosen tetap dalam melaksanakan kegiatan-kegiatan Tridaharma Perguruan Tinggi adalah sebesar 40.5 jam per-minggu. Beban kerja dosen normal dosen tersebut terdiri dari (Heri Sudarsono, 2008:75): “(1) Kegiatan pendidikan (jumlah 27.5 jam per-minggu): terdiri dari mengajar 2 mata kuliah, membimbing skripsi, perwalian mahasiswa, sidang sarjana, dan membuat diktat kuliah; (2) Kegiatan penelitian (jumlah 11 jam per-minggu) : terdiri dari penelitian (sebagai peneliti utama) dan penulisan makalah di jurnal terakreditasi; (3) Kegiatan pengabdian pada masyarakat (jumlah 1 jam per-minggu) : berupa pelatihan insidental; (4) Kegiatan penunjang (jumlah 1 jam per-minggu) : berupa partisipasi dalam kepanitiaan tertentu."

Dari uraian kutipan di atas jelas bahwa dosen berkinerja baik harus mampu melaksanakan tiga kegiatan sebagai tugasnya di Pergurun Tinggi, Khususnya IAIN Langsa. Ketiga kegiatan dimaksud adalah kegiatan pendidikan dan pengajaran, melaksanakan penelitian dan melakukan pengamdian kepada masyarakat. Jika kegiatan ini dapat dilaksanakan dosen dengan baik, maka dosen akan memperoleh predikat kinerja baik. Maka, dengan kinerja yang baik, berarto dosen akan memberikan kontribusi besar dalam mendorong pencapaian tujuan perguruan tinggi. Dengan demikian, kinerja dosen IAIN Langsa adalah tumpuan harapan dalam pencapaian tujuan.

Kinerja dosen merupakan persoalan yang urgen dibicarakan di tingkat perguruan tinggi. Di kalangan IAIN Langsa, kinerja dosen menjadi harapan semua elemen masyarakat dalam mempercepat terlaksananya Syari'at Islam bagi masyarakat. Sehingga kinerja dosen selalu menjadi tuntutan paling utama dalam merumuskan visi, misi dari IAIN Langsa. Dalam melaksanakan misinya, IAIN Langsa selalu berupaya dengan melaksanakan berbagai kegiatan akademik dengan harapan kinerja dosen dapat ditingkatkan. Akan tetapi, tidak semua IAIN dapat meningkatkan kinerja dosen secara maksimal. Karena, kinerja dosen dapat saja dipengaruhi oleh bermacam-macam per- 
soalan dalam melaksanakan aktivitas pada setiap perguruan tinggi.

Kinerja dosen adalah kemampuan yang mampu dilakukan dosen menyelesaikan program kerjanya dalam waktu tertentu dalam mendukung pencapaian tujuan lembaga. Sehing, kinerja dosen dapat dinilai baik dan buruk adalah dari hasil pencapaiannya oleh setiap dosen. Kinerja dosen merupakan keberhasilan kerja dosen dalam menyelesaikan tugas-tugasnya yang telah ditentukan oleh lembaga dalam masa waktu yang ditentukan. Menurut Ari Cahyono, sebagaimana yang dituliskan pada sebuah srtikel dalam Jurnal Ilmu Manajemen, Revitalisasi, bahwa: "Kinerja adalah hasil kerja yang telah dicapai seseorang dalam melaksanakan tugas yang menjadi anggung jawabnya dalam kurun waktu tertentu dan menurut kriteria pengukuran dinas. Dengan indikator: 1) Kualitas; 2) Kuantitas; 3) Ketepatan waktu”. (Cahyono, 2012: 283-298).

Robbins, S.P., dan Mary Coulter Menjelaskan Bahwa: "performance is all of these. It's the end result of an activity and whether that activity is hours of intense practice before a consert or race or whether it's carrying out job responsibility as efficiently and effectively as possible, performance is what results from that activity" Robbins, S.P., dan Marry, C. 2007 :564). Kinerja itu harus dilihat dari hasil yang dikerjakan dalam jangka waktu tertentu dengan pertimbangan efektif dan efisien. Lebih lanjut Colquitt, dkk, berpendapat: " job performance is formally defined as the value of the set of employee behaviors that contribute, either positively or negatively, to organizational goal accomplishment".

Apabila dikaitan dengan kinerja dosen, maka dosen yang berkinerja baik adalah dosen yang memberikan hasil kerja maksimal dalam melaksanakan tugas-tugasnya secara efektif dan efisien dalam mendukung pencapaian tujuan organisasi atau lembaga. Demikian sebaliknya, dosen ktegori kinerja buruk adalah dosen yang belum menunjukkan hasil kerja sesuai target dan tujuan yang ingin dicapai. Dosen berkinerja buruk tidak dapat menuntaskan tugas-tugasnya secara efektif dan efisien dalam pencapaian tujuan organisasi atau lembaga.

Menurut Torang, S (2013) memberikan penjelasan bahwa “ Kinerja (Performance) adalah kuantitas dan kualitas hasil kerjaindividu atau kelompok di dalam organisasi dalam melaksanakan tugas pokok dan fungsi yang berpedoman pada norma, standar operasional prosedur, kriteria dan ukuran yang telah ditetapkan atau yang berlaku dalam organisasi”( Jason A. Colquitt, Jeffery A. Lipine, Michael J. Wesson. 2009: 37). Maka, hasil kerja dosen dalam menyelesaikan tugasnya, juga harus sesuai prosedur kerja atau standar operasional prosedur yang telah ditetapkan.

Persoalan kinerja merupakan pembahasan paling urgen di lingkunan perguruan tinggi. Sebab kinerja menjadi variabel berpengaruh terhadap kemajuan sebuah lembga 
ataupun organisasi. Perguruan tinggi yang maju disebabkan adanya kontribusi kinerja yang cukup baik oleh seluruh civitas akademika di perguruan tinggi tersebut. Banyak perguruan tinggi ingin memperbaiki dan meningkatkan kinerja karyawan dan dosen, dengan harapan berpengaruh terhadap kemajuan lembaga. Maka hampir semua pimpinan perguruan tinggi di Provinsi Aceh, terutama IAIN Langsa terus melakukan analisis dari berbagai faktor atau variabel yang mempengaruhi kinerja dosen. Karena, asumsi yang paling signifikan adalah banyak variabel yang dapat mempengaruhi dan meningkatkan kinerja dosen.

Dari hasil penelitian Jason A. Colquitt, Jeffery A. Lipine, Michael J. Wesson memberikan gambaran bahwa kinerja seorang pegawai/kariawan atau dosen pada sebuah lembaga/organisasi dipengaruhi langsung oleh kepuasan kerja. Sedangkan kepuasan kerja itu sendiri dipengaruhi oleh budaya organisasi dan kepemimpinan. Tetapi kerangka konseptual hasil penelitian Qolquitt bertententangan dengan paradigma yang dikembangkan oleh John W. Newstrom yang dikenal dengan "Integrative Model of Organizational Behavior" yakni yang mempengaruhi Kinerja kariawan/pegawai secara langsung bukanlah kepuasan kerja, melainkan kepuasan kerja itu sendiri menjadi variabel outcomes sebagai variabel yang dipengaruhi (John W. Newstrom. 2007: 26). Dari kedua kerangka konseptual ini memberikan perbedaan pandangan yang jelas. Menurut John W. Newstrom, Kinerja dan kepuasan kerja adalah variabel endogen yang dipengaruhi oleh beberapa variabel exogen. Sementara itu, Qolquitt memandang bahwa kinerja sebagai hasil akhir sebagai variabel endogen yang dipengaruhi oleh kepuasan kerja. Dalam hal ini, Qolquitt tidak menempat kepuasan kerja sebagai variabel yang selevel dengan kinerja.

Banyak hasil-hasil penelitian tentang manajemen menemukan bahwa kinerja dipengaruhi oleh berbagai faktor, diantaranya gaya kepemimpinan, budaya organisasi, kepuasan kerja dan komitmen organisasi. Komitmen organanisasi berkemungkinan memberikan pengaruh keepada kinerja secara langsung.

Komitmen organisasi merupakan suatu upaya dari setiap anggota organisasi untuk tetap mempertahankan dirinya sebagai anggota organisasi dalam rangka meraih tujuan yang diinginkan dicapai oleh organisasi. Benyamin Sitimorang menuliskan pengertian komitmen organisasi dalam disertasinya bahwa "komitmen organisasi adalah keinginan anggota organisasi untuk tetap mempertahankan keanggotaannya dalam organisasi dan bersedia berusaha keras bagi pencapaian tujuan organisasi" ( Situmorang, 2012: 7).

Komitmen adalah faktor penting yang harus dijadikan sebuah perjanjian dan tanggung jawab pada setiap individu dalam bekerja. Karena dengan komitmen dapat mem- 
berikan pengakuan pada setiap anggota organisasi sebagai sikap seutuhnya yang berasal dari watak dan keluar dari setiap orang yang memang telah ada sejak lahir. Komitmen memberikan pengaruh yang besar terhadap pencapaian tujuan. Semua anggota organisasi bisa saja merasa puas dalam bekerja apabila kinerjanya sesuai dengan komitmen yang ada. Karena sesungguhnya komitmen akan menuntut sikap realistis, dan tidak mudah mengyakan sesuatu, akan tetapi sesuatu itu akan dilaksanakan dengan penuh tanggungjawab.

Komitmen merupakan faktor yang paling berpengaruh dalam organisasi. Organisasi yang memiliki komitmen kuat, maka pegawai atau anggota organisasi dalam bekerja akan mampu menunjukkan kinerja yang baik dan puas dalam bekerja. Anggota organisasi merasa puas dalam bekerja sehingga mampu menunjukkan kinerja yang tinggi sebagai anggota organisasi. Banyak teori dan hasil-hasil penelitian yang mengemukakan tentang komitmen mampu mempengaruhi kepuasan karyawan dalam bekerja. Diantaranya, hasil penelitian yang ditulis oleh Ching-Sheng Chang dalam Western Journal of Nursing Research 2015 dengan judul Moderating Effects of Nurses' Organizational Support on the Relationship Between Job Satisfaction and Organizational Commitment menyimpulkan: "A cross- sectional survey was sent to 400 nurses; 386 valid questionnaires were collected, with a valid response rate of $96.5 \%$. According to the research findings, nurses' job satisfaction has a positive and significant influence on organizational commitment" (Ching-Sheng Chang, 2015 : 724-745). Kesimpulan dari penelitian ini memberikan arti bahwa kepuasan kerja memberikan pengaruh terhadap komitmen organisasi secara signifikan.

Selanjutnya, Taurisa , C.M. dan Intan Ratnawati dalam laporan penelitiannya menuliskan pada kesimpulan ke tiga bahwa "kepuasan kerja berpengaruh secara positif dan signifikan terhadap komitmen organisasi" (Taurisa , C.M. dan Intan Ratnawati, 2012: 170 - 187). Hasil penelitian ini memberikan bukti secara empiris adalah kepuasan kerja sepatutnya dapat diciptakan oleh setiap pegawai atau dosen pada sebuah perguruan tinggi. Karena kepuasan kerja pegawai mampu mempengaruhi komitmen organisasi dan kemudian mempengaruhi kinerja pegawai organisasi itu sendiri.

Kepuasan kerja akan dirasakan oleh pegawai atau dosen pada sebuah Perguruan dalam melaksanakan tugas-tugasnya. Tentunya, pekerjaan dosen dapat dilaksanakan dengan baik karena di dukung oleh berbagai faktor lain. Faktor-faktor tersebut akan dirasakan oleh dosen dalam bekerja. Salah satu faktor yang mempengaruhi kepuasan dosen dalam bekerja adalah gaya kepemimpinan yang berlangsung pada pergutuan tinggi ia bekerja. Demikian juga pegawai pada sebuah organisasi lainnya, akan merasakan puas dalam melaksanakan pekerjaannya, jika gaya kepemeimpinan yang ia rasakan sangat mendukung dalam melaksanakan pekerjaan. 
Kepuasan kerja dapat diartikan sebagai sikap positif karyawan atau pegawai terhadap tugas yang dilaksanakan, yang timbul berdasarkan penilaian terhadap situasi kerja. Situasi kerja yang menyenangkan akan hadir pada diri pegawai/karyawan pabila sifat dan jenis pekerjaan yang sedang dikerjakan sesuai dengan kebutuhan, keahlian, cukup fasilitas, adanya dukungan moril, dan sesuai kemampuannya. Dengan demikian, mereka yang puas adalah mereka merasakan senang terhadap situasi pekerjaanya. Sehingga perasaan puas akan lahir pada situasi kerja yang sedang dilaksanakan. karyawan yang puas lebih menyukai situasi kerjanya dari pada karyawan yang tidak puas, yang tidak menyukai situasi kerjanya (Taurisa, C.M. dan Intan Ratnawati, 2012: 173).

Kinerja dosen di IAIN Langsa sudah sepatutnya dianalisis untuk memperoleh informasi tentang faktor apa saja yang menyebabkan kinerja mengalami penurunan dan adanya peningkatan.

Dari hubungan kausal variabel di atas, mengundang satu pertanyaan baru bagi penulis adalah seberapa kuatkah pengaruh setiap variabel-variabel tersebut secara langsung dan tidak langsung kepada Kinerja Dosen di IAIN Langsa. Untuk menjawab pertanyaan tersebut, peneliti berkeinginan untuk melakukan suatu penelitian dengan judul: Pengaruh Kepuasan Kerja, dan Komitmen Organisasi Terhadap Kinerja Dosen IAIN Langsa Tahun Akademik 2015/2016. Berdasarkan latar belakang masalah dan identifikasi masalah yang terlah di uraikan, maka dirumuskan beberapa permasalahan dalam penelitian ini sebagai berikut: Apakah kepuasan kerja dosen berpengaruh langsung terhadap Kinerja Dosen, dan Apakah Komitmen Organisasi berpengaruh terhadap Kinerja Dosen.

\section{PEMBAHASAN}

\section{Uji Validitas Instrumen}

Untuk memperoleh data yang diperlukan, maka penelitian ini perlu menguji instrumen yang dapat mengukur data sesungguhnya dengan teknik analisis validitas menggunakan rumus korelasi product moment sebagai berikut:

$$
r x y=\frac{n\left(\sum x_{i} y_{i}\right)-\left(\sum x_{i}\right) \cdot\left(y_{i}\right)}{\sqrt{\left[n \cdot \sum \cdot X_{i}^{2}-\left(\sum X_{i}\right)^{2}\right] \cdot\left[n \cdot \sum \cdot Y_{i}^{2}-\left(\sum Y_{i}\right)^{2}\right]}}
$$

Untuk menggunakan rumus tersebut data dapat dihitung dengan cara cepat dengan program SPSS. Perhitungan dengan rumus korelasi yang telah diformat dengan program SPSS ini akan diperoleh nilai akhir $\left(r_{x y}\right)$ berdasarkan input data yang dilakukan. Untuk menentukan validnya setiap butir pertanyaan diputuskan bahwa apabila dari 
hasil perhitungan diperoleh nilai korelasi $r_{x y}>0,3$ maka butir pertnyaan dikatakan valid. Sedang nilai korelasi $r_{x y}<0,3$ dikatakan tidak valid.

Berdasarkan input data di lapangan melalui survey angket yang telah disebarkan dengan tahap uji coba instrumen ini diperoleh hasil pada setiap uji coba instrumen sebagai berikut:

a. Instrumen Kepuasan Kerja $\left(\mathrm{X}_{1}\right)$

Instrumen kepuasan kerja terdiri dari 10 butir pertanyaan yang dimulai dari nomor butir pertanyaan nomor 12 sampai dengan nomor 21. Dari kesepuluh butir pertanyaan dihitung nilai korelasinya dan masing-masing butir diperoleh gambaran berikut: Hasil perhitungan uji validitas intrumen kepuasan kerja, jumlah pertanyaan yang valid adalah 7 pertanyaan yaitu nomor pertanyaan 1, 2, 3, 4, 7, 8, dan 9. Sedangkan yang tidak valid adalah 3 butir pertanyaan, yakni nomor butir 5, 6 dan 10. Secara keseluruhan instrumen berkaitan dengan kepuasan kerja dosen menjadi 7 pertanyaan.

b. Instrumen Komitmen Organisasi $\left(\mathrm{X}_{2}\right)$

Instrumen Komitmen Organisasi $\left(\mathrm{X}_{2}\right)$ terdiri dari 11 butir pertanyaan yang dimulai dari nomor butir pertanyaan nomor 22 sampai dengan nomor 32. Dari sebelas butir pertanyaan dihitung nilai korelasinya dan masing-masing butir pertanyaan diperoleh berikut: intrumen komitmen organisasi, jumlah pertanyaan yang valid adalah 8 pertanyaan yaitu nomor pertanyaan 1, 2, 3, 5, 6, 7, dan 8 . Sedangkan yang tidak valid adalah 2 butir pertanyaan, yakni nomor butir 9, 10 dan 11. Secara keseluruhan instrumen berkaitan dengan kepuasan kerja dosen menjadi 8 pertanyaan.

c. Instrumen Kinerja Dosen $\left(\mathrm{X}_{3}\right)$

Instrumen Kinerja Dosen $\left(\mathrm{X}_{3}\right)$ terdiri dari 11 butir pertanyaan yang dimulai dari nomor butir pertanyaan nomor 1 sampai dengan nomor 11. Dari sebelas butir pertanyaan dihitung nilai korelasinya dan masing-masing butir pertanyaan diperoleh gambaran berikut: Hasil perhitungan uji validitas intrumen Kinerja Dosen $\left(\mathrm{X}_{3}\right)$, jumlah pertanyaan yang valid adalah 9 pertanyaan yaitu nomor pertanyaan 1, 2, 3, 5, 6, 8, 9, 10 dan 11. Sedangkan yang tidak valid adalah 2 butir pertanyaan, yakni nomor butir 4 dan 7 . Secara keseluruhan instrumen berkaitan dengan kinerja dosen menjadi 9 pertanyaan.

Dari hasil analisis uji coba instrumen, maka dapat ditetapkan jumlah butir instrumen kinerja dosen $\left(\mathrm{X}_{3}\right)$ adalah 9 butir pertanyaan, untuk instrumen Komitmen Organisasi adalah 8 butir pertanyaan dan instrumen kepuasan kerja adalah 7 butir pertanyaan. Sehingga jumlah butir pertanyaan kesemua variabel yang telah disahkan/ ditetapkan 
sebagai angket dalam penelitian ini adalah 24 butir pertanyaan. Kesemua butir pertanyaan dituangkan dalam sebuah bentuk angket yang valid dan reliabel sebagaimana terdapat pada lampiran.

\section{Multikolinearitas}

Uji Multikolinearitas dilakukan untuk mengetahui apakah ada multikolinearitas atau tidak ada diantara variable bebas dengan variable terikat. Terdapatnya korelasi yang sempurna atau tidak sempurna pada variable-variabel bebas (independent variables) yang dilambangkan dengan $\mathrm{X}_{1}$, dan $\mathrm{X}_{2}$. Jika terjadi multikolinearitas pada variable-variabel bebas akan berakibat koefisien regresi tidak dapat ditentukan dan standard deviasi akan memiliki nilai tidah terhingga.

Hasil perhitungan dapat dilihat dari nilai toleransi atau VIF (Variance Inflation Factor) dari masing-masing variable. Jika nilai toleransi $<0,10$ atau VIF $>$ 5, maka terdapat multikolineritas, sehingga variabel tersebut harus dibuang atau sebaliknya. Dari hasil perhitungan computer dengan program SPSS versi 16, diperoleh nilai toleransi dan nilai VIF untuk masing-masing tahapan penelitian, adalah sebagai berikut: Multikolinearitas terjadi jika nlai VIF lebih besar dari 5, Hasil penelitian semua variable bebas yakni Kepuasan Kerja, dan Komitmen Organisasi berturut-turut memiliki nilai 1,064 $\left(X_{1}\right), 1,029\left(X_{2}\right)$. Dimana nilai-nilai ini adalah lebih kecil dari 5, sehingga dapat disimpulkan dari uji ini adalah mode regresi tidak terdapat problem multikolinearitas.

\section{Uji Normalitas}

Untuk melihat apakah data yang dianalisis memiliki nilai residual berada di sekitar nol (data normal). Untuk menguji normalitas data menggunakan hasil uji multification Kolmogorof-Smirnov (K-S). Jika K-S < nilai table, berarti data normal dan jika K-S > nilai table, berarti tidak normal.

Untuk memperoleh hasil yang akurat perhitungan dilakukan dengan menggunakan computer dengan program SPSS versi 16.0, dengan hasil bahwa uji dengan K-S terbukti diperoleh nilai residual mengikuti sebaran normal, karena Asymp. Sig (2-tailed) >0.05.

\section{Pengujian Hipotesis}

Pengujian hipotesis dalam penelitian ini diuji dengan menggunakan statistik Analisis Jalur (Path Analysis). Dimana pengujian dilakukan dengan terlebih dahulu menyusun hipotesis dengan membuat model-model struktur. Dimana model-model struktur yang dimunculkan dalam hipotesis diperoleh sebagai berikut: 


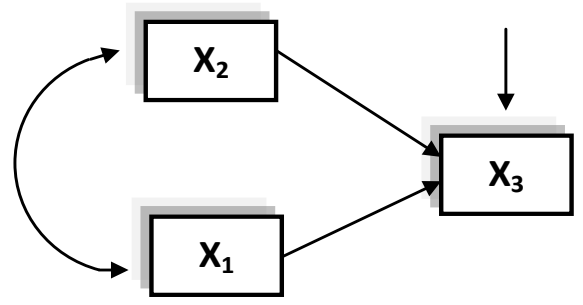

Keterangan:

$\mathrm{X}_{1}=$ Kepuasan Kerja

$\mathrm{X}_{2}=$ Komitmen Organisasi

$\mathrm{X}_{3}=$ Kinerja Dosen

Gambar 1. Model Struktur Sebagai Konseptual Penelitian

Pada gambar 1. di atas merupakan model struktur yang menunjukkan bahwa vaeiabel $X_{1}$, dan variabel $X_{2}$ adalah dua variabel eksogen. Sedangkan variabel $\left(X_{3}\right)$ merupakan variabel endogen. Dari gambar model Struktur tersebut dapat memberikan suatu persamaan sebagai berikut:

$$
X_{3}=f\left(x_{1}, x_{2}\right)
$$

Sehingga persamaan linear struktur menjadi:

$$
X_{3}=\rho x_{3} x_{1} X_{1}+\rho x_{3} x_{2} X_{2}+\rho \varepsilon_{1}
$$

Keterangan:

$$
\begin{array}{ll}
X_{1} & =\text { Kepuasan Kerja } \\
X_{2} & =\text { Komitmen Organisasi } \\
X_{3} & =\text { Kinerja Dosen } \\
\varepsilon_{1} & =\text { Epsilon } 1
\end{array}
$$

Dari model struktur di atas dapat diuji hipotesis statistik dengan langkah-langkah sebagai berikut:

\section{Hipotesis-1}

$H_{0}: \rho x_{3} x_{1}=0$; tidak terdapat pengaruh Kepuasan Kerja terhadap kepuasan kinerja dosen.

$\mathrm{H}_{\mathrm{a}}: \rho \mathrm{x}_{3} \mathrm{x}_{1} \neq \mathrm{o}_{;}$terdapat pengaruh Kepuasan Kerja terhadap kepuasan kinerja dosen. 
Berdasarkan analisis menggunakan uji regresi dengan bantuan aplikasi SPSS diperoleh hasil perhitungan sebagai berikut:

Tabel 1.

Koefesien Pengujian Hipotesis Variabel

Kepuasan Kerja Terhadap Kinerja Dosen

Coefficients $^{\text {al }}$

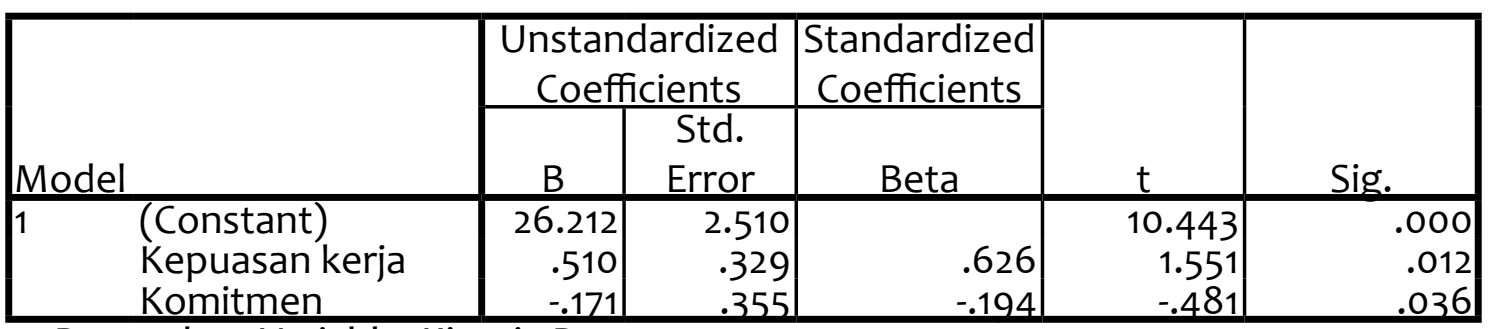

a. Dependent Variable: Kinerja Dosen

Uji signifikansi analisis jalur dicari yaitu dengan membandingkan anatara nilai probabilitas 0,05 dengan probabilitas siq. Dasar pengambilan keputusan sebagai berikut:

- Jika nilai porobabilitas 0,05 lebih kecil atau sama dengan nilai probabilitas siq atau (0,05 $\leq$ sig), maka Ho diterima dan Ha ditolak, artinya tidak signifikan.

- Jika nilai probabilitas 0,05 lebih besar atau sama dengan nilai probabilitas sig atau (0,05 $\geq$ sig), maka Ho ditolak dan Ha diterima, artinya signifikan.

Terlihat bahwa pada kolom sig (sugnifikan) pada tabel 4.6. di atas di dapat nilai sig. 0,012. ini menunjukan bahwa nilai probabilitas lebih besar dari nilai signifikan. Maka dalam hal ini hipotesis Ho ditolak. Dengan demikian disimpulkan bahwa terdapat pengaruh secara signifikan kepuasan kerja berpengaruh kepada kinerja dosen.

\section{Hipotesis-2}

$H_{0}: \rho x_{3} x_{2}=0$; tidak terdapat pengaruh kepemimpinan terhadap kepuasan kerja dosen $H_{a}: \rho x_{3} x_{2} \neq 0$; terdapat pengaruh kepemimpinan terhadap kepuasan kerja dosen

Berdasarkan tabel 4.6. di atas menunjukkan bahwa nilai signifikan variabel komitmen organisasi menunjukkan angka 0,036. Ini memberiakn arti bahwa hal yang sama seprti variabel kepuasan kerja bahwa nilai probabilitas lebih besar dari nilai signifikan. Maka dalam hal ini Ho juga ditolak dan terima Ha. Sehingga disimpulkan bahwa komitmen organisasi memberikan pengaruh kepada kinerja dosen. 
Untuk menentukan persamaan linear struktur yang telah ditulis di atas maka nilai-nilai koefisien dimasukkan ke dalam persamaan regresi linear, sehingga diperoleh persamaan sebagai berikut:

$$
X_{3}=\rho x_{3} x_{1} X_{1}+\rho x_{3} x_{2} X_{2}+\varepsilon_{1}
$$

Apabila $X_{3}$ sebagai variabel endogen dan dapat diganti dengan $\mathrm{Y}$ atau $\left(\mathrm{X}_{3}=\mathrm{Y}\right)$, maka persamaan dapat ditulis sebagai berikut:

$$
Y=\rho x_{3} x_{1} X_{1}+\rho x_{3} x_{2} X_{2}+\rho \varepsilon_{1}
$$

Dengan memasukkan nilai-nilai koefisien jalur sebagaimana terdapat pada tabel diperoleh persamaan:

$$
Y=0,626 X_{1}-0,194 X_{2}+0,806 \varepsilon_{1}
$$

Diamana nilai $\varepsilon_{1}$ diperoleh dari persamaan:

$$
\rho \varepsilon_{1}=1-R_{y \times 1 \times 2}^{2}=1-0,194=0,806
$$

Nilai $R_{y \times 1 \times 2}^{2}$ diperoleh dari hasil analisis Summary $X_{1}$ dan $X_{2}$ terhadap kinerja $(Y)$ atau $\mathrm{X}_{3}$ dan ditunjukkan oleh tabel berikut:

Tabel 2.

\begin{tabular}{|c|c|c|c|c|}
\hline Model & $\mathrm{R}$ & R Square & $\begin{array}{c}\text { Adjusted R } \\
\text { Square }\end{array}$ & $\begin{array}{c}\text { Std. Error of the } \\
\text { Estimate }\end{array}$ \\
\hline 1 & $.440^{\mathrm{a}}$ & 194 & |174 & 2.213 \\
\hline
\end{tabular}

Model Summary Kepuasan Kerja dan Komitmen Terrhadap Kinerja Dosen

\section{Model Summary}

A. Predictors: (constant), komitmen, kepuasan kerja

Sedangkan penjelasan secara deskriptif terhadap kedua variabel berkenaan dengan nilai rata-rata, digambarkan pada tabel 4.8. berikut:

Tabel 3 .

Nilai Rata-Rata Skor Variabel Kepuasan Kerja

Komitmen Organisasi, dan Kinerja Dosen

Descriptive Statistics

\begin{tabular}{|l|r|r|r|}
\hline & \multicolumn{1}{|c|}{ Mean } & Std. Deviation & $\mathrm{N}$ \\
\hline Kinerja dosen & 35.61 & 2.435 & 84 \\
Kepuasan kerja & 27.80 & 2.989 & 84 \\
Komitmen & 27.92 & 2.765 & 84 \\
\hline
\end{tabular}


Dari tabel 4.8 di atas memberikan arti bahwa dari 84 responden yang dijadikan sampel, bahwa pada perolehan data kinerja dosen memperoleh nilai atau skor rata-rata 35,61. Sedangkan pada pengisian angket atau perolehan data kepuasan kerja memberikan skor rata-rata adalah 27,80 , dan pada variabel komitmen organisasi memberikan skor rata-rata 27,92.

\section{KESIMPULAN}

Berdasarkan tujuan penelitian yang ingin dicapai dan sesuai dengan hasil analisis penelitian yang dilakukan dengan pengujian hipotesis, maka dapat ditarik beberapa kesimpulan penelitian sebagai berikut:

1. Terdapat pengaruh secara signifikan bahwa kepuasan kerja memberikan pengaruh kepada kinerja dosen di IAIN Langsa. Hal ini dibuktikan dengan adanya penolakan Ho dan terima Ha dengan nilai probabilitas $(0,05)>$ nilai signifikan $(0,012)$.

2. Terdapat Pengaruh Komit secara signifikan bahwa komitmen lembaga/organisasi memberikan pengaruh kepada kinerja dosen IAIN Langsa. Hal ini dibuktikan dengan adanya penolakan Ho dan terima Ha dengan nilai probabilitas $(0,05)>$ nilai signifikan $(0,036)$. 


\section{DAFTAR PUSTAKA}

Armanu Thoyib. Hubungan Kepemimpinan, Budaya, Strategi, dan Kinerja, Jurnal manajemen \& kewirausahaan. http://puslit.petra.ac.id/ puslit/journals. 2005, p. 3-4. Jurusan Ekonomi Manajemen, Fakultas Ekonomi - Universitas Kristen Petra.

Ayesha Farooq t dan Dinney Mathew K.t (2009). Impact of Authority Decentralization on Organizational Commitment: An Empirical Study of Development Projects in Kerala. Management And Labour Studies Journals, 1, (34), p. 27-42.

Asfiah, N. Budaya Organisasi (2015)., http: //nurulasfiah. staff.umum.ac.id/ 2010/01/05/-organisasi, diakses tangaal 04 September 2015, p.1.

Cahyono, A. (2012). Analisa Pengaruh Kepemimpinan, Motivasi Dan Budaya Organisasi Erhadap Kinerja Dosen Dan Karyawan Di Universitas Pawyatan Daha Kediri, Jurnal Ilmu Manajemen, Revitalisasi, 1 (1), p. 283-298.

Ching-Sheng Chang. (2015). Moderating Effects of Nurses' Organizational Support on the Relationship Between Job Satisfaction and Organizational Commitment, 37, (6), p. 724-745.

Heri Sudarsono, (2008). Analisis Pengaruh Kompensasi terhadap Motivasi, Journal Penelitian Kependidikan, 18, (1), oktober 2008, Fakultas Ekonomi Universitas Teknologi Surabaya, Jl. Ketintang Surabaya

John W. Newstrom. (2007). Orgazational Behavior, Human Behavior at Work, Singapore: McGraw-Hill, p. 100.

Jason A. Colquitt, Jeffery A. Lipine, Michael J. Wesson (2009). Organization Behavior: Improving Performance and Commitment in the Workplace. New York:The McGraw-Hill Com., Inc., p. 37.

Robbins, S.P., dan Marry, C. (2007). Management: Peorson International Edition. United States of America: Pearson Prentice Hall, p. 564.

Torang, S. (2013). Organisasi dan Manajemen. Bandung: Alfabeta.

Taurisa , C.M. dan Intan Ratnawati. (2012). Analisis pengaruh budaya organisasi dan kepuasan kerja terhadap Komitmen organisasional dalam meningkatkan kinerja karyawan (studi pada pt. Sido muncul kaligawe semarang), Jurnal Bisnis dan Ekonomi (JBE), 19 (2): p. $170-187$ 